\title{
HUBUNGAN ANTARA KEJADIAN ASITES PADA CIRRHOSIS HEPATIS DENGAN KOMPLIKASI SPONTANEOUS BACTERIAL PERITONITIS
}

\author{
Meddy Setiawan*
}

\begin{abstract}
Abstrak
Cirrhosis Hepatis merupakan hasil akhir dari jejas hepatoseluler yang ireversibel dan menimbulkan fibrosis dan regenerasi nodular pada hepar. Retensi air dan garam tampak jelas sebagai manifestasi klinis pada semua kasus Cirrhosis Hepatis disebut asites. Spontaneous Bacterial Peritonitis adalah komplikasi ketiga terbesar pada pasien dengan Cirrhosis Hepatis walaupun komplikasi tersebut dapat tampak pada pasien asites karena sebab yang lain.

Tujuan penelitian ini adalab membuktikan adanya hubungan antara asites pada penderita Cirrbosis Hepatis dengan komplikasi Spontaneous Bacterial Peritonitis. Metode yang digunakan adalah deskriptif analitik dengan data yang diambil dari rekam medis pasien asites rawat inap di Bagian Penyakit Dalam Rumah Sakit Syaiful Anwar Malang pada tahun 2006 (1 Januari 1 - 31 Desember 2006). Data dianalisis dengan menggunakan Uji Chi-Square dan Uji Korelasi Kontingensi.

Hasil penelitian menunjukekan, dari tabulasi silang penderita asites dengan Cirrbosis Hepatis dan komplikasi Spontaneous Bacterial Peritonitis, $48 \%$ terdiagnosis Cirrbosis Hepatis dan $52 \%$ non Cirrbosis. 51 \% mengalami komplikasi Spontaneous Bacterial Peritonitis dengan 63 \% nya terdiagnosa Cirrhosis Hepatis. Hal ini menunjukkan bahwa Komplikasi Spontaneous Bacterial Peritonitis lebih banyak. muncul pada pasien Cirrhosis Hepatis daripada dengan pasien Non-Cirrhosis Hepatis.

Kesimpulan penelitian ini adalab adanya hubungan yang signifikan antara ascites pada penderita Cirrbosis Hepatis dengan Komplikasi Spontaneous Bacterial Peritonitis dengan basil uji Chi-Square $\left(c^{2}\right)=9,066$ dengan $p=0.003(\dot{a}<0,05)$ dan basil uji Korelasi Kontingensi $=0.288$ dengan $p=0.003(a ́<0,05)$ menunjuk.kan keeratan yang positif.
\end{abstract}

Kata Kunci : Cirrhosis Hepatis - Asites - Spontaneous Bacterial Peritonitis (SBP)

\footnotetext{
* Bagian Ilmu Penyakit Dalam, Fakultas Kedokteran

Universitas Muhammadiyah Malang
} 


\section{Abstract}

Cirrhosis Hepatis is the end result of hepatocellular injury that is generally irreversible and leads to both fibrosis and nodular regeneration throughout the liver. Sodium and water retention occur in virtually all cases of Cirrhosis Hepatis, even before fluid accumulation is detectable clinically within the peritoneal space, and it is called ascites. Spontaneous Bacterial Peritonitis is the first three occur most commonly in patients with Cirrhosis and ascites, although they may occur in patients with other causes of ascites.

The aim of this study is to prove the correlation between ascites in Cirrhosis Hepatis and its complication to Spontaneous Bacterial Peritonitis from it approach with the clinical manifestasion of Cirrbosis Hepatis, ascites, and Spontaneous Bacterial Peritonitis. Material and method are taken from ascitic patients' medical report whose hospitalized at Syaiful Anwar Hospital Malang in 2006 (1 ${ }^{\text {st }}$ January - 31 st December 2006). Datas were analyzed with descriptive analytic using Chi-Square study and Contingency Correlation approach.

Using cross tabulation method shows, that $48 \%$ of the patients were diagnosed with Cirrhosis Hepatis and $52 \%$ with non - Cirrhosis Hepatis. $51 \%$ had complication to Spontaneous Bacterial Peritonitis, with $62 \%$ were diagnosed with Cirrhosis Hepatis. It explains that Spontaneous Bacterial Peritonitis' complication which appears in ascitic patients with Cirrbosis Hepatis is more prevalent compare to nonCirrhosis Hepatis ascitic patients.

The results of this research shows that, ascites in Cirrhosis Hepatis and its manifestation to Spontaneous acterial Peritonitis have a significant correlation by Chi-Square $\left(x^{2}\right)$ 9,066 with $p=0,003(a<0,05)$, and Contingency Correlation 0,288 with $p=0,003$ $(\dot{a}<0,05)$.

Keyword : Cirrhosis Hepatis, Ascites, Spontaneous Bacterial Peritonitis (SBP)

\section{PENDAHULUAN}

Cirrbosis Hepatis $(\mathrm{CH})$ merupakan penyebab kematian terbesar ketiga di negara berkembang pada pasien yang berusia diatas 45 tahun (setelah penyakit kardiovaskuler dan kanker). Diseluruh dunia, Cirrhosis Hepatis menempati urutan ketujuh penyebab kematian. Sekitar 25.000 orang meninggal setiap tahun akibat penyakit ini. Cirrbosis Hepatis merupakan penyakit hati yang sering ditemukan dalam ruang perawatan Bagian Penyakit Dalam. (Sutadi, 2003). Di Indonesia, data prevalensi Cirrbosis Hepatis belum ada, hanya laporan-laporan dari beberapa pusat pendidikan saja. Di RS Dr. Sardjito Yogyakarta, dalam kurun waktu 4 tahun ditemukan 819 penderita Cirrhosis Hepatis dari seluruh pasien di bagian Penyakit Dalam. (Nurdjanah, 2006)

Asites merupakan manifestasi kardinal dari penderita Cirrbosis Hepatis, yaitu penimbunan cairan serosa dalam rongga peritoneum. $80 \%$ penderita Cirrhosis Hepatis di Amerika menunjukkan adanya asites. Beberapa faktor yang turut terlibat dalam patogenesis asites pada Cirrhosis Hepatis antara lain adalah hipertensi portal.

Peritonitis merupakan komplikasi tersering pada penderita Cirrbosis Hepatis yang disertai dengan asites. 10-30\% penderita Cirrbosis Hepatis dengan asites mengalami komplikasi berupa peritonitis. Bentuk peritonitis yang paling sering adalah Spontaneous Bacterial Peritonitis. Spontaneous Bacterial Peritonitis (SBP) terjadi bukan karena infeksi abdomen, namun biasanya terjadi pada pasien dengan asites akibat penyakit hati kronis, dalam hal ini Cirrhosis Hepatis. Angka kematian dari Spontaneous
Bacterial Peritonitis cukup tinggi, yaitu sekitar $50 \%$. (Claude, 1996).

Banyaknya angka kejadian asites pada penderita Cirrbosis Hepatis seperti yang diuraikan di atas, akan lebih meningkatkan resiko terjadinya Spontaneous Bacterial Peritonitis, sehingga meningkatkan angka morbiditas dan mortalitas penderita Cirrbosis Hepatis, yang akhirnya menurunkan pruduktivitas. Untuk itulah pada penelitian ini menarik untuk diteliti hubungan antara kejadian Cirrbosis Hepatis yang disertai asites dengan komplikasi Spontaneous Bacterial Peritonitis.

Tujuan umum dalam penelitian ini adalah untuk membuktikan adanya hubungan antara asites pada penderita Cirrhosis Hepatis dengan komplikasi Spontaneous Bacterial Peritonitis.

Pengertian Cirrhosis Hepatis dapat dikatakan sebagai berikut yaitu suatu keadaan disorganisasi yang difus dari struktur hati yang normal akibat nodul regeneratif yang dikelilingi jaringan mengalami fibrosis. (Sutadi, 2003). Gambaran ini terjadi akibat nekrosis hepatoseluler, kolapsnya jaringan penunjang retikulin disertai deposit jaringan ikat, distorsi jaringan vaskular, dan regenerasi nodularis parenkim hati sisanya. Proses patologik harus dipandang sebagai akhir dari perjalanan berbagai jenis cedera hati kronik. (Podolsky, 2005)

Klasifikasi histologis Cirrbosis dibagi menjadi: Mikronoduler, makronoduler, dan bentuk campuran (mixed forms). Masing-masing bentuk tersebut dapat dilihat pada pasien yang sama, dengan penyakit yang berbeda stadiumnya. Pada sirosis mikronodular, tipe penyakit hati alkoholik (Laenec's 
Cirrhosis), regenerasi nodul tidak lebih besar dari lobulus pada umumnya, diameternya kira-kira tidak lebih dari $1 \mathrm{~mm}$. Macronodular Cirrhosis ditandai dengan nodul yang lebih besar, yang dapat berkembang diameternya sampai beberapa sentimeter dan bisa saja didapatkan dilatasi vena central.

Klasifikasi Cirrhosis Hepatis menurut Childpugh juga digunakan sebagai dasar diagnosis Cirrhosis Hepatis

Tabel 1

Klasifikasi Child-pugh :

\begin{tabular}{|l|c|c|c|}
\hline Skor/parameter & $\mathbf{1}$ & $\mathbf{2}$ & $\mathbf{3}$ \\
\hline Bilirubin (mg\%) & $<2,0$ & $2-<3$ & $>3,0$ \\
\hline Albumin (\%) & $>3,5$ & $2,8-<3,5$ & $<2,8$ \\
\hline Protbrombin time (\%) & $>70$ & $40-<70$ & $<40$ \\
\hline Asites & 0 & $\begin{array}{c}\text { Minimal }- \text { sedang } \\
(+)-(++)\end{array}$ & Banyak $(+++)$ \\
\hline Hepatic enchepalopatby & $(-)$ & Std.I dan Std.II & Std.III dan IV \\
\hline
\end{tabular}

(Sumber : FKUI, 2006)

Derajat 1 merupakan derajat kerusakan minimal, dimana disebutkan oleh Tarigan (1996) bahwa pada derajat ini merupakan derajat kompensasi sempurna, sehingga kadang-kadang sulit menegakkan diagnosis Cirhhosis Hepatis. Pada proses lanjutan dari kompensasi sempurna (derajat 2) mungkin bisa ditegakkan diagnosis dengan bantuan pemeriksaan klinis yang cermat, laboratorium biokimia/serologi marker, dan pemeriksaan penunjang lainnya. Pada derajat ini,penegakan diagnosis Cirrhosis Hepatis terdiri atas pemeriksaan fisik, laboratorium, USG. Pada kasus tertentu diperlukan pemeriksaan biopsy hati/ peritenoskopi. Sulit membedakan hepatitis kronik aktif yang berat dengan sirosis hepatis dini.

Suharyono Soebandiri memformulasikan bahwa 5 dari 7 tanda di bawah ini sudah dapat menegakkan diagnosis Cirrbosis Hepatis dekompensata: Asites, Splenomegali, Perdarahan varises (hematemesis), Kadar albumin yang rendah, Spider Nevi, Erythema Palmaris, Vena collateral. (Tarigan, 1996)

Di negara barat, alkohol merupakan penyebab utama Cirrhosis Hepatis, sedangkan di Indonesia terutama akibat infeksi virus hepatitis B maupun C. Hasil penelitian di Indonesia menyebutkan virus hepatitis B menyebabkan Cirrhosis sebesar $40-50 \%$, dan virus hepatitis C sebesar $30-40 \%$, sedangkan $10-20 \%$ penyebabnya tidak diketahui dan termasuk kelompok virus bukan B dan C (non B - non C). (Nurdjanah, 2006)

Akibat masukan alkohol, infeksi hepatitis virus tipe $\mathrm{B} / \mathrm{C}$, atau toxin lain, mengakibatkan destruksi hepatosit yang berkepanjangan, muncul fibroblas (termasuk miofibroblas yang memiliki kemampuan berkontraksi) di tempat cedera dan merangsang pembentukan kolagen. Di zona periportal dan perisentral muncul septa jaringan ikat seperti jaring yang akhirnya menghubungkan triad portal dengan vena sentralis. Jalinan jaringan ikat halus ini mengelilingi massa kecil sel hati yang masih ada, yang lalu mengalami regenerasi dan membentuk nodulus. Walaupun terjadi regenerasi dalam sisa-sisa parenkim, kerusakan sel biasanya melebihi perbaikannya. Akibat destruksi hepatosit dan penimbunan kolagen yang berkelanjutan, ukuran hati menciut, tampak berbenjol-benjol (noduler), dan menjadi keras karena berbentuk Cirrhosis "stadium akhir". (Podolsky, 2005)

Sumber utama pembentukan kolagen pada Cirrhosis Hepatis terutama terjadi pada sel stelata hepatik perisinusoidal (sel Ito), yang terdapat di Space of Disse. Walaupun pada umumnya berfungsi sebagai sel penyimpan vitamin A, sel-sel tersebut teraktivasi sejalan dengan terjadinya Cirrhosis Hepatis, penyimpanan retinil ester menghilang, dan berubah menjadi sel seperti myofibroblas. Stimuli dari sintesis dan deposisi dari kolagen juga dapat bersumber dari:

- Inflamasi kronis, dengan produksi sitokin inflamasi seperti Tumor Necrosis Factor (TNF)-á, Transforming Growth Factor (TGF)-â, dan interleukin-1

- Produksi sitokin dari sel endogen yang terstimulasi (sel Kupffer, sel endotel, hepatosit, dan sel epitel duktus biliaris)

- Disrupsi dari matrix extraselular.

- Stimulasi langsung dari sel stelata oleh toxin. (Cotran, 1999) 
Sekuele utama Cirrhosis Hepatis adalah hipertensi portal. Tekanan portal yang normal adalah antara 5-10 mmHg. Pada hipertensi portal terjadi kenaikan tekanan dalam sistem portal yang lebih dari $15 \mathrm{mmHg}$ dan bersifat menetap. Keadaan ini akan menyebabkan limpa membesar (splenomegali), pelebaran pembuluh darah kulit pada dinding perut disekitar pusar (caput medusae), pada dinding perut yang menandakan sudah terbentuknya sistem kolateral, wasir (hemorrboid), dan penekanan pembuluh darah vena esofagus atau cardia (varices oesophagus) yang dapat menimbulkan muntah darah (hematemesis), atau berak darah (melena). Kalau pendarahan yang keluar sangat banyak maka penderita bisa timbul syok (renjatan). Perjalanan penyakit pasien Cirrhosis tahap lanjut biasanya dipersulit oleh sejumlah sekuele penting yang tidak bergantung pada etiologi penyekit hati yang mendasari, seperti timbul asites, ensefalopati, dan perubahan ke arah kanker hati primer (hepatoma). (Podolsky, 2005)

Gangguan metabolik yang bermacam-macam juga bisa didapatkan. Intoleransi glukosa karena resistensi insulin endogen, walaupun secara klinis, jarang disertai diabetes. Hiperventilasi sentral dapat terjadi akibat alkalosis respiratorik. Peningkatan pelepasan urine diakibatkan hipomagnesemia dan hipofosfatemia. Pada pasien dengan asites dan hiponatremi dilusional, hipokalemi terjadi karena meningkatnya pengeluaran potassium lewat urine yang disebabkan oleh hipoaldosteronisme. Prerenal azotemia juga ditemukan pada beberapa pasien. (Podolsky, 2005)

Salah satu manifestasi dari Cirrhosis Hepatis adalah menurunnya kadar albumin. Albumin merupakan protein plasma yang paling banyak dalam tubuh manusia, yaitu sekitar $55-60 \%$ dari protein serum yang terukur.Albumin terdiri dari rantai polipeptida tunggal dengan berat molekul $66,4 \mathrm{kDa}$ dan terdiri dari 585 asam amino. Pada molekul albumin terdapat 17 ikatan disulfida yang menghubungkan asam-asam amino yang mengandung sulfur. Molekul albumin berbentuk elips sehingga bentuk molekul seperti itu tidak akan meningkatkan viskositas plasma dan terlarut sempurna. Kadar albumin serum ditentukan oleh fungsi laju sintesis, laju degradasi dan distribusi antara kompartemen intravaskular dan ektravaskular. Cadangan total albumin sehat (70 $\mathrm{kg}$ ) dimana $42 \%$ berada di kompartemen plasma dan sisanya dalam kompartemen ektravaskular.

Sintesis albumin hanya terjadi di hepar dengan kecepatan pembentukan 12-25 gram/hari. Pada keadaan normal hanya $20-30 \%$ hepatosit yang memproduksi albumin. Akan tetapi laju produksi ini bervariasi tergantung keadaan penyakit dan laju nutrisi karena albumin hanya dibentuk pada lingkungan osmotik, hormonal dan nutrisi yang cocok. Tekanan osmotik koloid cairan interstisial yang membasahi hepatosit merupakan regulator sintesis albumin yang penting.

Degradasi albumin total pada dewasa dengan berat $70 \mathrm{~kg}$ adalah sekitar 14 gram/hari atau $5 \%$ dari pertukaran protein seluruh tubuh per hari. Albumin dipecah di otot dan kulit sebesar 40$60 \%$, di hati $15 \%$, ginjal sekitar $10 \%$ dan $10 \%$ sisanya merembes ke dalam saluran cerna lewat dinding lambung. Produk degradasi akhir berupa asam amino bebas. Pada orang sehat kehilangan albumin lewat urine biasanya minimal tidak melebihi10-20 mg/hari karena hampir semua yang melewati membran glomerolus akan diserap kembali.

Komplikasi yang sering dijumpai pada penderita Cirrhosis Hepatis adalah Spontaneous Bacterial Peritonitis, yaitu infeksi cairan asites oleh satu jenis bakteri tanpa ada bukti infeksi sekunder intraabdominal. Biasanya pasien ini tanpa gejala, namun dapat timbul demam dan nyeri abdomen. Kerusakan hati lanjut menyebabkan penurunan perfusi ginjal yang berakibat pada penurunan filtrasi glomerolus. Ensefalopati hepatik merupakan kelainan neuropsikiatrik akibat disfungsi hati. Pada sindrom hepatopulmonal terdapat hidrothoraks dan hipertensi portopulmonal. (Nurdjanah, 2006)

Kebanyakan pasien dengan Cirrbosis Hepatis kadang-kadang terjadi peningkatan cairan dalam abdomen atau yang disebut dengan asites, dapat meningkatkan resiko terjadinya infeksi intraabdominal spontan.

Perdarahan varises. Perdarahan adalah hal yang tersering dari varises pada daerah gastroesophageal junction. Faktor yang mempengaruhi belum jelas, tapi menyangkut derajat hipertensi portal $(>12 \mathrm{mmHg})$ dan ukuran dari varises. Splenomegali kongestif sering dijumpai pada pasien dengan hipertensi portal karena meningkatnya aliran darah pada vena lien. Asites, umum dijumpai pada pasien dengan Cirrbosis atau kelainan hati yang lain. Sindroma hepatorenal, berhubungan dengan bertambah parahnya azotemia dengan retensi sodium dan oligouri yang merupakan penyebab disfungsi renal. (Podolsky, 2005)

Spontaneous Bacterial Peritonitis adalah infeksi cairan asites oleh satu jenis bakteri tanpa ada bukti infeksi sekunder intraabdominal. Biasanya pasien ini tanpa gejala, namun dapat timbul demam dan nyeri abdomen. (Nurdjanah, 2006) 
Spontaneous Bacterial Peritonitis dapat disebabkan karena perforasi usus yang dapat menyebabkan masuknya organisme patogen ke dalam rongga peritoneum. (Lingappa, 2000)

Agen yang berperan dalam etiologi Spontaneous Bacterial Peritonitis kebanyakan adalah monobakterial, yang pada umumnya adalah flora intestinal (>90\%). $3 / 4$ kasus Spontaneous Bacterial Peritonitis disebabkan oleh organisme aerob gram negatif (50\% nya adalah Eschericia coli), dan $1 / 4$ nya disebabkan oleh organisme aerob gram positif (19\% pneumococci). Organisme anaerob jarang karena cairan asites memiliki tekanan oksigen yang tinggi. (Bandy, 2006)

Cairan asites merupakan medium kultur yang baik untuk beberapa patogen, termasuk Enteobacteriaceae (khususnya $E$ coli), group D streptokokus (enterokokus), Streptococcus pneumoniae, dan Streptococcus viridan. (Lingappa, 2000)

Ada sebuah argumen yang mengatakan bahwa Spontaneous Bacterial Peritonitis terjadi akibat migrasi transmural bakteri dari usus halus atau lumen organ, yaitu fenomena yang disebut translokasi bakterial. Tetapi, kenyataan eksperimental mengatakan, bahwa migrasi transmural secara langsung belum tentu mengakibatkan Spontaneous Bacterial Peritonitis. Mekanisme lain mengatakan, organisme infeksius dengan mudah menyebar secara hematogen apabila dikaitkan dengan sistem pertahanan imun yang kurang. Beberapa faktor yang mempengaruhi antara lain: pertumbuhan bakteri dalam usus, disertai dengan fungsi fagositik, serum yang rendah dan level komplemen dari asites, penurunan fungsi retikuloendotelial, dapat meningkatkan jumlah mikroorganisme dan menurunkan kapasitas untuk membersihkan organisme-organisme tersebut melalui peredaran darah. Menariknya, pasien dewasa dengan Spontaneous Bacterial Peritonitis pada umumnya disertai asites, tapi kebanyakan pasien anak-anak tidak disertai asites. Alasan dan mekanisme dibalik sumber ini masih menjadi investigasi selanjutnya. (Bandy, 2006)

Perhitungan sel polimorfonuklear diatas 250 $\mathrm{sel} / \mathrm{mm}^{3}$ pada cairan asites sudah menunjukkan diagnosis Spontaneous Bacterial Peritonitis dan segera memerlukan pengobatan antibiotika. (Parsi, 2004)

Kultur bakteri aerob dan anaerob dapat menjadi tuntunan dalam penatalaksanaan Spontaneous Bacterial Peritonitis. Studi lain yang perlu diperhatikan: Sitologi, Laktat; level laktat asites $>25 \mathrm{mg} / \mathrm{dL}$ dan pH cairan asites $<7,35$ (Bandy, 2006)

Konsentrasi protein yang rendah (hipoalbumin) pada cairan asites berkaitan dengan tingginya resiko terjadinya Spontaneous Bacterial
Peritonitis pada penderita Cirrhosis Hepatis dengan asites. Penelitian pada 127 penderita Cirrhosis Hepatis dengan asites, ditemukan lima variabel yang berkaitan dengan tingginya resiko Spontaneous Bacterial Peritonitis, tetapi hanya protein cairan asites dibawah $1 \mathrm{gr} / \mathrm{dL}$ yang menguatkan prediksi. Dua penelitian selanjutnya juga menemukan hasil yang sama.

\section{Metodologi Penelitian : Rancangan Penelitian}

Rancangan penelitian yang digunakan adalah deskriptif analitik dengan pendekatan cross sectional.

\section{Populasi}

Seluruh penderita asites yang rawat inap di bagian Penyakit Dalam RSSA Malang pada tahun 2006 (1 Januari - 31 Desember 2006).

\section{Sampel}

Penderita Cirrhosis Hepatis, Congestive Heart Failure, Nephrotic Syndrome, malnutrisi, Meig's Syndrome yang disertai asites, yang rawat inap di bagian Penyakit Dalam RSSA Malang pada tahun 2006 (1 Januari - 31 Desember 2006) yang memenuhi kriteria inklusi dan eksklusi dari penelitian.

\section{Cara Pemilihan Sampel}

Menggunakan rumus perkiraan besar sampel, yang dipakai adalah rumus besar sampel untuk data nominal untuk sampel tunggal dengan menggunakan ketepatan absolute.

Apabila tingkat kepercayaan yang dikehendaki sebesar 95\%, PxQ mempunyai nilai paling tinggi untuk $\mathrm{P}=0,50$, ketepatan absolut yag diinginkan sebesar $10 \%$, dan bila proporsi sebelumnya tidak diketahui, maka besar sampel minimal yang diperlukan adalah :

$$
\begin{aligned}
& \mathrm{n}=\frac{(1,960)^{2} \times(0,50) \times(1-0,50)}{(0,10)^{2}} \\
& \mathrm{n}=96,04 \\
& \mathrm{n}=97
\end{aligned}
$$

\section{Kriteria Inklusi}

Adalah : Penderita dengan asites (Cirrhosis Hepatis, Congestive Heart Failure, Malnutrisi, Nephrotic Syndrome, Meig's Syndrome), Pria dan wanita, tanpa batasan usia. 


\section{Kriteria Eksklusi}

Adalah : Penderita Spontaneous Bacterial Peritonitis dengan riwayat parasentesa, penderita peritonitis sekunder akibat enteritis, dan infeksi organ abdomen.

\section{Variabel Penelitian}

Variabel bebas adalah asites dan Variabel tergantung adalah Spontaneous Bacterial Peritonitis

\section{Tempat dan Waktu Penelitian}

Penelitian akan dilaksanakan di bagian Penyakit Dalam RSSA Malang mulai bulan November 2007 - Januari 2008.

\section{Definisi dan Konsep Operasional}

Cirrhosis Hepatis adalah suatu akhir dari perjalanan berbagai jenis cedera hati kronik dan irreversibel. Diagnosa pasti Cirrhosis Hepatis didasarkan pada pemeriksaan fisik, laboratorium, dan USG.

- Asites adalah penimbunan cairan secara abnormal dalam rongga abdomen. Asites sangat mudah dikenali pada inspeksi, akan tampak perut membuncit, pada umumnya gizi kurang, otot atrofi. Dan pada pemeriksaan fisik, didapatkan pekak alih atau Shifting Dullness (+).

Albumin merupakan protein yang terbesar dalam plasma darah dan diproduksi oleh hepar. Albumin berperan dalam mengatur tekanan onkotik plasma. Kadar normal albumin serum antara 30-50 gr/dL. Kadarnya menurun pada penderita dengan asites, dan didapatkan dari pemeriksaan laboratorium darah lengkap.

- Spontaneous Bacterial Peritonitis adalah infeksi cairan asites oleh satu jenis bakteri tanpa ada bukti infeksi sekunder intraabdominal, yang diagnosanya ditegakkan berdasarkan aspirasi cairan asites, dari pemeriksaan laboratorium, dan dengan kultur bakteri (+).

\section{Teknik Pengumpulan Data}

Diperoleh dari data sekunder yaitu Rekam Medik penderita asites, yang akan diolah berdasarkan :Karakteristik penderita, gejala klinis, pemeriksaan fisik, dan pemeriksaan laboratorium.

\section{Analisa Data}

Menggunakan deskriptif analitik dan disajikan dalam bentuk tabel frekuensi distribusi. Kemudian data tersebut dikelompokkan menjadi 4 kelompok:

1. Kelompok A (Asites pada Cirrhosis dengan SBP $(+))$

2. Kelompok B (Asites pada Cirrhosis dengan SBP $(-))$

3. Kelompok C (Asites pada Non-Cirrhosis dengan SBP $(+))$

4. Kelompok D (Asites pada Non-Cirrhosis dengan SBP (-))

Hubungan antara asites pada Cirrhosis Hepatis, dengan kejadian Spontaneous Bacterial Peritonitis dilakukan uji Chi-Square menggunakan program SPSS for Windows versi 10.0, dengan derajat kepercayaan 95\%, á=0,05 bermakna bila $\mathrm{p}<0,05$ dengan koefisien kontigensi (r) sebagai ukuran dari keeratan hubungan antara asites pada Cirrhosis Hepatis, dengan kejadian Spontaneous Bacterial Peritonitis.

\section{Hasil Penelitian dan Pembahasan}

Responden yang disertai dengan asites yang berjumlah 100 orang, diteliti keterkaitannya dengan kejadian Cirrhosis Hepatis dan komplikasi Spontaneous Bacterial Peritonitis. Hasil rekapitulasi distribusi frekuensi yang terkumpul tentang karakteristik responden tersebut diperoleh sebagai berikut.

\section{Distribusi Usia Responden}

Deskripsi berdasarkan usia dari responden yang mengalami asites, disajikan dalam tabel sebagai berikut.

Tabel 2

Karakteristik Usia Responden dengan Asites

\begin{tabular}{|c|c|c|}
\hline Usia (tahun) & Frekuensi & Persentase (\%) \\
\hline$<30$ & 6 & $6 \%$ \\
$30-39$ & 10 & $10 \%$ \\
$40-49$ & 37 & $37 \%$ \\
$50-59$ & 20 & $20 \%$ \\
$60-69$ & 17 & $17 \%$ \\
$=70$ & 10 & $10 \%$ \\
\hline Total & $\mathbf{1 0 0}$ & $\mathbf{1 0 0} \%$ \\
\hline
\end{tabular}

Sumber : Data yang diolah, 2009 
Berdasarkan analisa yang telah dilakukan peneliti, didapat bahwa rentang terbesar usia responden yang mengalami asites adalah antara 4049 tahun, sebanyak $37 \%$, lalu terbanyak kedua, adalah antara 50-59 tahun, sebanyak 20\%.

\section{Distribusi Jenis Kelamin}

Distribusi frekuensi berdasarkan jenis kelamin responden, didapatkan hasil sebagai berikut.

Tabel 3

Distribusi Jenis Kelamin Responden

\begin{tabular}{|c|c|c|}
\hline Jenis kelamin & Frekuensi & Persentase (\%) \\
\hline Laki-laki & 57 & $57 \%$ \\
Perempuan & 43 & $43 \%$ \\
\hline Total & 100 & $100 \%$ \\
\hline
\end{tabular}

Sumber : Data yang diolah, 2009

Berdasarkan analisa yang dilakukan peneliti, didapatkan bahwa responden pria lebih banyak atau sekitar 57\% daripada wanita yang hanya $43 \%$.

\section{Gejala Klinis Cirrhosis Hepatis}

Deskripsi gejala klinis terhadap pendekatan diagnosa Cirrhosis Hepatis diuraikan dalam tabel berikut.

Tabel 4

Distribusi Frekuensi Gejala Klinis Cirrhosis Hepatis

\begin{tabular}{|l|c|c|c|c|c|}
\hline \multirow{2}{*}{ Gejala Klinis } & \multicolumn{4}{|c|}{ Hasil } & \multirow{2}{*}{$\begin{array}{c}\text { Total } \\
\text { (\%) }\end{array}$} \\
\cline { 2 - 5 } & \multicolumn{2}{|c|}{ Positif (+) } & \multicolumn{2}{c|}{ Negatif (-) } & \\
\cline { 2 - 5 } & Frek & $\mathbf{( \% )}$ & Frek & $\mathbf{( \% )}$ & \\
\hline Asites & 100 & $\mathbf{1 0 0}$ & - & - & 100 \\
\hline Nyeri Adomen & 38 & $\mathbf{3 8}$ & 62 & $\mathbf{6 2}$ & 100 \\
\hline Dyspepsia & 73 & $\mathbf{7 3}$ & 27 & $\mathbf{2 7}$ & 100 \\
\hline Shifting Dullness & 59 & $\mathbf{5 9}$ & 41 & $\mathbf{4 1}$ & 100 \\
\hline
\end{tabular}

Sumber : Data yang diolah, 2009

Berdasarkan distribusi gejala klinis yang ditemukan dari 100 responden, didapatkan : Sebanyak $100 \%$ responden mengalami asites. Sebanyak 38\% responden mengalami nyeri abdomen, $73 \%$ responden mengalami Dyspepsia, dan $59 \%$ responden dengan Shifting Dullness positif.

\section{Pendekatan Diagnosa Cirrhosis Hepatis}

Pada penelitian ini, penulis meneliti gejala klinis yang diambil dari rekam medis responden, yang digunakan untuk dasar diagnosis Cirrhosis Hepatis.

Tabel 5

Distribusi Frekuensi Pendekatan Diagnosa Cirrhosis Hepatis

\begin{tabular}{|c|c|c|}
\hline Pendekatan Diagnosa & Frekuensi & Persentase (\%) \\
\hline Non Cirrhosis Hepatis & 52 & $52 \%$ \\
Cirrosis Hepatis & 48 & $48 \%$ \\
\hline Total & $\mathbf{1 0 0}$ & $\mathbf{1 0 0 \%}$ \\
\hline
\end{tabular}

Sumber : Data yang diolah, 2009 
$86 \quad$ Vol.7 No. 15 Desember 2011

\section{Gejala Klinis Spontaneous Bacterial Peritonitis}

Gejala klinis Spontaneous Bacterial Peritonitis yang sering dijumpai adalah ditemukannya distensi abdomen, demam, peningkatan leukosit diatas $10.000 \mathrm{sel} / \mathrm{mm}^{3}$, dan penurunan kadar albumin dibawah $3,5 \%$.

Tabel 6

Distribusi Frekuensi Gejala Klinis Spontaneous Bacterial Peritonitis

\begin{tabular}{|c|c|c|c|c|c|}
\hline \multirow[b]{2}{*}{ No } & \multirow[b]{2}{*}{ Gejala Klinis } & \multicolumn{2}{|c|}{ SBP } & \multirow{2}{*}{$\begin{array}{c}\text { Chi square } \\
\text { dan } p\end{array}$} & \multirow{2}{*}{$\begin{array}{c}\text { Korelasi } \\
\text { dan p }\end{array}$} \\
\hline & & $\begin{array}{c}(-) \\
n=49\end{array}$ & $\begin{array}{c}(+) \\
n=51\end{array}$ & & \\
\hline 1 & $\begin{array}{c}\text { Distensi Abdomen } \\
(-) \\
(+) \\
\end{array}$ & $\begin{array}{l}29 \\
20 \\
\end{array}$ & $\begin{array}{c}4 \\
47 \\
\end{array}$ & $\begin{array}{c}29,792 \\
p=0,000\end{array}$ & $\begin{array}{l}r=0,479 \\
p=0,000\end{array}$ \\
\hline 2 & $\begin{array}{c}\text { Leuko sit }>10.000 \mathrm{sel} / \mathrm{mm}^{3} \\
(-) \\
(+)\end{array}$ & $\begin{array}{l}33 \\
16 \\
\end{array}$ & $\begin{array}{l}14 \\
37 \\
\end{array}$ & $\begin{array}{c}15,968 \\
p=0,000\end{array}$ & $\begin{array}{l}r=0,371 \\
p=0,000\end{array}$ \\
\hline 3 & $\begin{array}{c}\text { Albumin }<3,5 \% \\
(-) \\
(+) \\
\end{array}$ & $\begin{array}{c}9 \\
40 \\
\end{array}$ & $\begin{array}{c}2 \\
49 \\
\end{array}$ & $\begin{array}{c}5,327 \\
p=0,021\end{array}$ & $\begin{array}{l}r=0,225 \\
p=0,021\end{array}$ \\
\hline 4 & $\begin{array}{l}\text { Suhu tubuh }>37,5^{\circ} \mathrm{C} \\
\qquad 37^{\circ} \mathrm{C} \\
\quad=37^{\circ} \mathrm{C}\end{array}$ & $\begin{array}{l}39 \\
10 \\
\end{array}$ & $\begin{array}{c}1 \\
50 \\
\end{array}$ & $\begin{array}{c}62,752 \\
p=0,000\end{array}$ & $\begin{array}{l}r=0,621 \\
p=0,000\end{array}$ \\
\hline
\end{tabular}

Sumber : Data yang diolah, 2009

\section{Pendekatan Diagnosa Spontaneous Bacterial Peritonitis}

Pada penelitian ini, penulis meneliti gejala klinis yang diambil dari rekam medis responden, yang akan digunakan untuk pendekatan diagnosis Spontaneous Bacterial Peritonitis. Dari 100 orang responden yang telah didapatkan data gejala klinis yang menyertai, menurut distribusi di atas, didapatkan hasil sebagai berikut.

Tabel 7

Distribusi Frekuensi Pendekatan Diagnosis Spontaneous Bacterial Peritonitis

\begin{tabular}{|c|c|c|}
\hline Hasil diagnosa SBP & Frekuensi & Persentase (\%) \\
\hline$(-)$ & 49 & $49 \%$ \\
$(+)$ & 51 & $51 \%$ \\
\hline Total & $\mathbf{1 0 0}$ & $\mathbf{1 0 0} \%$ \\
\hline
\end{tabular}

Sumer : Data primer yang diolah, 2009

Dari data diatas dapat dijelaskan bahwa, dari 100 orang responden, ditemukan sebanyak 51 responden (51\%) mengalami komplikasi Spontaneous Bacterial Peritonitis, sedangkan 49 responden (49\%) tidak mengalami komplikasi Spontaneous Bacterial Peritonitis.

\section{Hasil Analisa Gejala Klinis terhadap Cirrhosis Hepatis}

Cirrhosis Hepatis dengan gejala klinis asites, nyeri abdomen, Dyspepsia, dan Shifting Dullness positif, memiliki hubungan yang dapat dilihat dari tabulasi silang sebagai berikut. 
Tabel 8

Hubungan antara Gejala Klinis dengan Pendekatan

Diagnosis Cirrhosis Hepatis

\begin{tabular}{|c|c|c|c|c|c|}
\hline \multirow[b]{2}{*}{ No } & \multirow[b]{2}{*}{ Gejala Klinis } & \multicolumn{2}{|c|}{$\mathrm{CH}$} & \multirow{2}{*}{$\begin{array}{c}\text { Chi square } \\
\text { dan } p\end{array}$} & \multirow{2}{*}{$\begin{array}{c}\text { Korelasi } \\
\text { dan p }\end{array}$} \\
\hline & & $\begin{array}{c}(-) \\
n=52\end{array}$ & $\begin{array}{c}(+) \\
\mathrm{n}=48\end{array}$ & & \\
\hline 1 & $\begin{array}{c}\text { Asites } \\
(-) \\
(+)\end{array}$ & $\begin{array}{c}0 \\
52\end{array}$ & $\begin{array}{c}0 \\
48\end{array}$ & - & - \\
\hline 2 & $\begin{array}{c}\text { Nyeri Abdomen } \\
(-) \\
(+)\end{array}$ & $\begin{array}{l}35 \\
17\end{array}$ & $\begin{array}{l}27 \\
21\end{array}$ & $\begin{array}{c}1,295 \\
p=0,255\end{array}$ & $\begin{array}{l}\mathrm{r}=0,113 \\
\mathrm{p}=0,255\end{array}$ \\
\hline 3 & $\begin{array}{c}\text { Dyspepsia } \\
(-) \\
(+)\end{array}$ & $\begin{array}{l}18 \\
34\end{array}$ & $\begin{array}{c}9 \\
39\end{array}$ & $\begin{array}{c}3,188 \\
p=0,074\end{array}$ & $\begin{array}{l}\mathrm{r}=0,176 \\
\mathrm{p}=0,074\end{array}$ \\
\hline 4 & $\begin{array}{c}\text { Shifting Dullness } \\
(-) \\
(+)\end{array}$ & $\begin{array}{l}20 \\
32\end{array}$ & $\begin{array}{l}21 \\
27\end{array}$ & $\begin{array}{c}0,289 \\
p=0,591\end{array}$ & $\begin{array}{l}\mathrm{r}=0,054 \\
\mathrm{p}=0,591\end{array}$ \\
\hline
\end{tabular}

Sumber : Data primer yang diolah, 2009

Berdasarkan Uji Chi-Square dari data diatas, dapat diuraikan satu per satu sebagai berikut : Untuk gejala klinis asites, tidak ditemukan nilai $C h i$ Square dan nilai korelasi, karena semua responden mengalami asites, sebagaimana asites masuk ke dalam kriteria inklusi dalam pengambilan sampel penelitian ini. Pada responden dengan gejala klinis nyeri abdomen, Dyspepsia, dan Shifting Dullness, ditemukan nilai $\mathrm{p}>0,05$ yang berarti, tidak menunjukkan adanya suatu hubungan yang signifikan terhadap Cirrhosis Hepatis. Hal ini disebabkan karena diagnosis Cirrhosis Hepatis ditegakkan melainkan berdasarkan gejala klinis yang didapat, juga berdasarkan pemeriksaan laoratorium dan USG abdomen. Oleh karena itu, masih banyak aspek yang perlu diteliti lagi untuk memastikan diagnosa Cirrhosis Hepatis.
Berdasarkan Uji Korelasi dari data di atas, gejala klinis nyeri abdomen, Dyspepsia, dan Shifting Dullness pada responden dengan asites, tidak menunjukkan adanya keeratan hubungan (korelasi $=\mathrm{r}$ ) yang kuat dan signifikan. Namun Dyspepsia masih cenderung memiliki keterkaitan yang lebih besar terhadap Cirrhosis Hepatis dengan asites dengan korelasi sebesar 0,176 .

\section{Hasil Analisa Gejala Klinis Terhadap Komplikasi Spontaneous Bacterial Peritonitis}

Spontaneous Bacterial Peritonitis dengan gejala klinis yang paling sering dijumpai berupa distensi abdomen, peningkatan leukosit diatas $10.000 \mathrm{sel} /$ $\mathrm{mm}^{3}$, penurunana kadar albumin dibawah 3,5\%, dan peningkatan suhu tubuh $>37^{\circ} \mathrm{C}$, memiliki hubungan yang dapat dilihat dari tabel berikut.

Tabel 9

Hubungan antara Gejala Klinis dengan Pendekatan

Diagnosis Spontaneous Bacterial Peritonitis

\begin{tabular}{|c|c|c|c|c|c|}
\hline \multirow{2}{*}{ No } & \multirow{2}{*}{ Gejala Klinis } & \multicolumn{2}{|c|}{ SBP } & \multirow{2}{*}{ Chi square } & Korelasi \\
\cline { 3 - 4 } & $\begin{array}{c}\mathbf{( - )} \\
\mathbf{n}=\mathbf{4 9}\end{array}$ & $\begin{array}{c}\mathbf{( + )} \\
\mathbf{n}=\mathbf{5 1}\end{array}$ & $\begin{array}{c}\text { dan } \mathbf{p} \\
\mathbf{d a n} \mathbf{p}\end{array}$ \\
\hline 1 & Distensi Abdomen & & & \\
& $(-)$ & 29 & 4 & 29,792 & $\mathrm{r}=0,479$ \\
& $(+)$ & 20 & 47 & $\mathrm{p}=0,000$ & $\mathrm{p}=0,000$ \\
\hline 2 & Leukosit $>10.000 \mathrm{sel} / \mathrm{mm}^{3}$ \\
$(-)$ & 33 & 14 & 15,968 & $\mathrm{r}=0,371$ \\
& $(+)$ & 16 & 37 & $\mathrm{p}=0,000$ & $\mathrm{p}=0,000$ \\
\hline
\end{tabular}


$88 \quad$ Vol.7 No. 15 Desember 2011

\begin{tabular}{|c|c|c|c|c|c|}
\hline 3 & $\begin{array}{c}\text { Albumin }<3,5 \% \\
(-)\end{array}$ & 9 & 2 & 5,327 & $\mathrm{r}=0,225$ \\
& $(+)$ & 40 & 49 & $\mathrm{p}=0,021$ & $\mathrm{p}=0,021$ \\
\hline 4 & Suhu tubuh $>37,5^{\circ} \mathrm{C}$ & & & & \\
& $<37^{\circ} \mathrm{C}$ \\
& $=37^{\circ} \mathrm{C}$ & 39 & 1 & 62,752 & $\mathrm{r}=0,621$ \\
& 10 & 50 & $\mathrm{p}=0,000$ & $\mathrm{p}=0,000$ \\
\hline
\end{tabular}

Sumber : Data primer yang diolah, 2009

Berdasarkan Uji Chi-Square dari data di atas, gejala klinis distensi abdomen, peningkatan leukosit diatas $10.000 \mathrm{sel} / \mathrm{mm}^{3}$, penurunana kadar albumin dibawah 3,5\%, dan peningkatan suhu tubuh $>37^{\circ}$ $\mathrm{C}$, memiliki nilai signifikansi $\mathrm{p}<0,05$ sehingga dapat disimpulkan bahwa ada hubungan yang signifikan antara keempat gejala klinis diatas dengan komplikasi Spontaneous Bacterial Peritonitis.

Dari Uji Korelasi gejala klinis di atas, didapatkan bahwa keempat gejala klinis di atas menunjukkan keeratan hubungan dengan komplikasi Spontaneous Bacterial Peritonitis dengan $\mathrm{p}<0,05$.
Tetapi, peningkatan suhu tubuh memiliki keeratan hubungan yang paling erat diantara keempat gejala klinis tersebut, yaitu dengan nilai korelasi 0,621.

\section{Hasil Analisa Hubungan antara Cirrhosis Hepatis dengan $\mathrm{K}$ o $\mathrm{m}$ p I $\mathrm{k}$ a $\mathrm{s}$ Spontaneous Bacterial Peritonitis}

Hubungan antara Cirrhosis Hepatis dengan Komplikasi Spontaneous Bacterial Peritonitis berdasarkan Uji Chi-Square dan Uji Korelasi disajikan dalam tabel sebagai berikut.

Tabel 10

Hubungan antara Cirrhosis Hepatis dengan Komplikasi Spontaneous Bacterial Peritonitis

\begin{tabular}{|c|c|c|c|c|c|}
\hline \multirow[b]{2}{*}{ No } & \multirow[b]{2}{*}{ Gejala Klinis SBP } & \multicolumn{2}{|c|}{ CH } & \multirow{2}{*}{$\begin{array}{c}\text { Chi square } \\
\text { dan p }\end{array}$} & \multirow{2}{*}{$\begin{array}{c}\text { Korelasi } \\
\text { dan } p\end{array}$} \\
\hline & & $\begin{array}{c}(-) \\
n=52\end{array}$ & $\begin{array}{c}(+) \\
n=48\end{array}$ & & \\
\hline 1 & $\begin{array}{c}\text { Distensi Abdomen } \\
(-) \\
(+)\end{array}$ & $\begin{array}{l}24 \\
28\end{array}$ & $\begin{array}{c}9 \\
39\end{array}$ & $\begin{array}{c}8,478 \\
p=0,004\end{array}$ & $\begin{array}{l}\mathrm{r}=0,280 \\
\mathrm{p}=0,004\end{array}$ \\
\hline 2 & $\begin{array}{c}\text { Leukosit }>10.000 \mathrm{sel} / \mathrm{mm}^{3} \\
(-) \\
(+)\end{array}$ & $\begin{array}{l}30 \\
22\end{array}$ & $\begin{array}{l}17 \\
31\end{array}$ & $\begin{array}{c}4,972 \\
p=0,026\end{array}$ & $\begin{array}{l}r=0,218 \\
p=0,026\end{array}$ \\
\hline 3 & $\begin{array}{c}\text { Albumin }<3,5 \% \\
(-) \\
(+)\end{array}$ & $\begin{array}{l}10 \\
42\end{array}$ & $\begin{array}{c}1 \\
47\end{array}$ & $\begin{array}{c}7,497 \\
p=0,006\end{array}$ & $\begin{array}{l}r=0,264 \\
p=0,006\end{array}$ \\
\hline 4 & $\begin{array}{c}\text { Suhu tubuh }>37,5^{\circ} \mathrm{C} \\
<37^{\circ} \mathrm{C} \\
=37^{\circ} \mathrm{C}\end{array}$ & $\begin{array}{l}27 \\
25\end{array}$ & $\begin{array}{l}13 \\
35\end{array}$ & $\begin{array}{c}6,417 \\
p=0,011\end{array}$ & $\begin{array}{l}r=0,246 \\
p=0,011\end{array}$ \\
\hline
\end{tabular}

Sumber : Data primer yang diolah, 2009

Dari data di atas, ditemukan semua nilai aspek Cirrhosis Hepatis terhadap komplikasi Spontaneous Bacterial Peritonitis memiliki nilai signifikansi $\mathrm{p}<0,05$, yang berarti, Spontaneous Bacterial Peritonitis memiliki hubungan yang signifikan terhadap Cirrhosis Hepatis. Sedangkan berdasarkan Uji Korelasi Kontingensi, juga menunjukkan adanya keeratan hubungan antara Cirrhosis Hepatis dengan komplikasi Spontaneous Bacterial Peritonitis.
Untuk menggambarkan penyebaran data secara lebih terinci mengenai hubungan antara Cirrhosis Hepatis dengan komplikasi Spontaneous Bacterial Peritonitis, dibentuk tabulasi silang (crosstabs) sebagai berikut. 
Tabel 11

Tabulasi Silang antara Cirrhosis Hepatis dengan Komplikasi

Spontaneous Bacterial Peritonitis

Crosstab

Count
\begin{tabular}{|lc|r|r|r|}
\hline \multirow{2}{*}{} & \multicolumn{2}{|c|}{ SBP } & \multirow{2}{*}{ Total } \\
\cline { 3 - 4 } & & $(-)$ & $(+)$ & 52 \\
\hline $\mathrm{CH}$ & $(-)$ & 33 & 19 & 48 \\
& $(+)$ & 16 & 32 & 100 \\
\hline
\end{tabular}

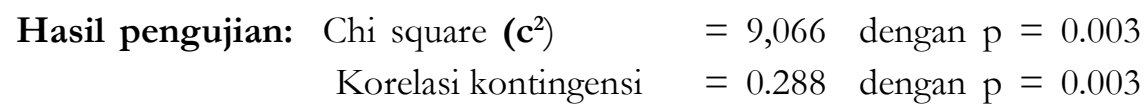

Berdasarkan hasil pengujian pada data di atas, dihasilkan nilai Chi-Square sebesar 9,066 yang lebih besar dari $\mathbf{c}^{2}$ tabel dengan $\mathrm{df}=1$, yaitu sebesar 3,841, dengan nilai signifikansi (p) sebesar 0.003 yang lebih kecil dari á 0.05. Sehingga dapat disimpulkan bahwa antara Cirrhosis Hepatis dengan Spontaneous Bacterial Peritonitis mempunyai hubungan yang signifikan. Berdasarkan tabel di atas, didapatkan nilai koefisien korelasi kontingensi sebesar 0,288 dengan nilai signifikansi (p) sebesar 0,003 yang lebih kecil dari á 0,05 . Hal ini berarti hipotesa yang menyatakan adanya keeratan hubungan antara Cirrhosis Hepatis dengan Spontaneous Bacterial Peritonitis, dapat diterima. Dengan kata lain antara Cirrhosis Hepatis dengan Spontaneous Bacterial Peritonitis mempunyai keeratan hubungan yang signifikan, dengan arah korelasi yang positif.

Adanya kaitan erat antara Cirrhosis Hepatis dengan terjadinya komplikasi Spontaneous Bacterial Peritonitis dapat digambarkan dalam bentuk histogram sebagai berikut.

\section{Grafik 1}

Hubungan Antara Cirrhosis Hepatis Dengan Terjadinya Komplikasi Spontaneous Bacterial Peritonitis

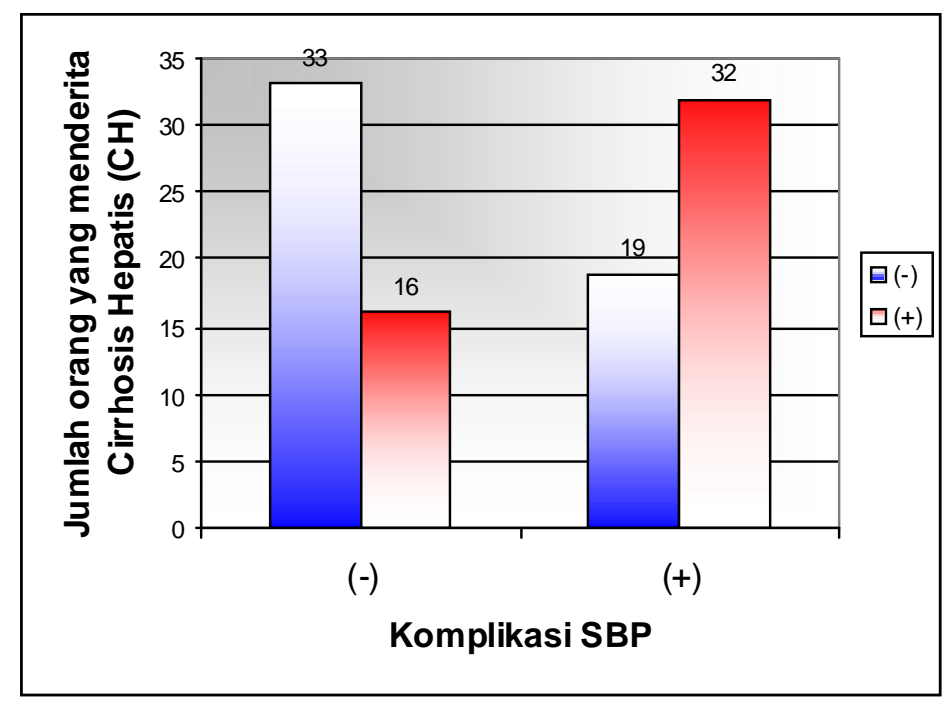

Sumber : Data primer yang diolah, 2009 
Dari diagram di atas dapat dijelaskan bahwa penderita asites dengan non Cirrhosis Hepatis yang tidak mengalami komplikasi Spontaneous Bacterial Peritonitis terdapat 33 orang, namun ada 19 orang responden yang mengalami komplikasi Spontaneous Bacterial Peritonitis. Pada responden asites dengan Cirrhosis Hepatis yang mengalami komplikasi Spontaneous Bacterial Peritonitis terdapat 32 orang, namun ada 16 responden yang tidak mengalami komplikasi Spontaneous Bacterial Peritonitis. Sehingga dapat dikatakan bahwa komplikasi Spontaneous Bacterial Peritonitis lebih banyak disebabkan oleh pasien asites karena Cirrhosis Hepatis, daripada pasien asites dengan non Cirrhosis Hepatis.

\section{Pembahasan}

Asites terjadi akibat tingginya tekanan portal yang disertai dengan kadar albumin yang rendah dan retensi natrium. (Davey, 2007)

Albumin dan protein-protein opsonik lainnya berperan protektif terhadap bakteri (Podolsky, 2005). Sehingga pada penderita asites akan lebih mudah untuk berkembang menjadi Spontaneous Bacterial Peritonitis. Belum ada sumber yang menyatakan seberapa banyak insiden asites dialami oleh kelompok umur tertentu. Tetapi, Podolsky (2005) mengatakan bahwa, asites akan jarang pada penderita Cirrhosis hepatis kecuali terdapat baik hipertensi portal maupun hipoalbuminemia. Selain itu, cairan limfe hepar yang merembes bebas dari permukaan hepar yang sirotik akibat distorsi dan sumbatan sinusoid-sinusoid, dan saluran limfe, ikut membentuk cairan asites. Hal ini sesuai dengan hasil penelitian yang menyebutkan bahwa dari 100 orang responden dengan asites, hanya 48\% yang terdiagnosis Cirrhosis hepatis.

Patofisiologi retensi air dan garam oleh ginjal pada gagal jantung (Congestive Heart Failure) menyebabkan aktivasi renin angiotensin aldosteron yang menyebabkan meningkatnya volume ventrikel dan regangan serabut jantung. Peningkatan beban awal ini akan menambah kontraktilitas miokardium sesuai dengan hukum Starling. Mekanisme pasti yang mengkibatkan aktivasi renin angiotensin aldosteron pada gagal jantung masih belum jelas. Namun diperkirakan terdapat sejumlah faktor seperti rangsangan simpatis adrenergik pada reseptor beta di dalam aparatus jukstaglomerolus, respon reseptor makula densa terhadap perubahan pelepasan natrium ke tubulus distal, dan respons baroreseptor terhadap perubahan volume dan tekanan darah sirkulasi. (Wilson, 2006)

Berdasarkan hasil penelitian terhadap 100 orang responden yang mengalami asites, didapatkan hasil berdasarkan distribusi frekuensi usia responden, paling banyak dialami oleh responden berusia 4049 tahun sebanyak 37\%, lalu setelah itu, dialami oleh responden yang berusia antara 50-59 tahun sebanyak $20 \%$. Belum ada sumber yang menjelaskan berapa insiden asites pada suatu kurun waktu tertentu, tetapi dapat dijelaskan menurut Wong (2002), bahwa asites didapatkan sebanyak 50\% dari penderita yang terdiagnosa Cirrhosis Hepatis selama 10 tahun. Hal ini merupakan indikator prognosis yang buruk, dengan 2 tahun survival rate sebanyak $50 \%$.

Menurut distribusi frekuensi berdasarkan jenis kelamin, responden pria lebih banyak, yakni $57 \%$, dan responden wanita sebanyak $43 \%$. Hal ini tidak menggambarkan perbedaan yang terlalu signifikan dalam hal jenis kelamin, yang berarti, resiko asites berpeluang hampir sama besar terhadap baik pria maupun wanita.

Dari 100 orang responden juga diklasifikasikan menjadi dua kelompok, yaitu yang masuk dalam kategori Cirrhosis hepatis, dan non Cirrhosis hepatis, yang dilakukan melalui pendekatan diagnosis berdasarkan gejala klinis yang dijumpai. Adapun gejala klinis yang diidentifikasi untuk melakukan pendekatan diagnosis Cirrhosis bepatis adalah : asites, nyeri abdomen, Dyspepsia, dan Shifting Dullness positif. Dari keempat aspek tersebut, didapatkan sebanyak $48 \%$ terdiagnosis Cirrhosis hepatis, dan sebanyak $52 \%$ non Cirrhosis. Hal ini disebabkan, pengelompokan non Cirrbosis bepatis termasuk di dalamnya, beberapa macam penyakit yang juga dapat menimbulkan asites, diantaranya gagal jantung kongestif, malnutrisi, sindroma nefrotik, Meig's Syndrome, dan lain-lain, sebagaimana tertulis pada usulan penelitian mengenai pemilihan sampel. Dari analisa menggunakan Uji Chi-Square dan Uji Korelasi mengenai pendekatan diagnosis Cirrhosis hepatis, ditemukan bahwa keempat gejala klinis yang menyertainya tersebut memang tidak memiliki hubungan yang signifikan terhadap terjadinya Cirrbosis hepatis. Tetapi, dyspepsia memiliki nilai yang lebih signifikan daripada gejala klinis lain yang ditemukan, hal ini membuktikan bahwa kebanyakan penderita Cirrhosis Hepatis mengalami dyspepsia, tetapi tetap bukan pedoman untuk pendekatan diagnosis Cirrbosis Hepatis. Nyeri abdomen hanya dialami oleh sebanyak 21 responden dengan asites. Tidak terbuktinya hubungan yang signifikan ini disebabkan karena, standar pasti diagnosis Cirrhosis hepatis ditegakkan melalui selain gejala klinis yang dapat terlihat, seperti splenomegali, caput medusae, hemorrhoid, varices oesophagus, hematemesis, melena, dan shock. Selain itu juga harus ditunjang 
dengan pemeriksaan laboratorium seperti pemeriksaan SGOT/SGPT, dan pemeriksaan USG abdomen. Dalam penelitian ini, peneliti hanya melihat dari sisi gejala klinis yang didapat dari rekam medis responden. Ini juga sebagai batasan dalam penelitian ini, sehingga menjadi saran bagi peneliti selanjutnya supaya dapat lebih terinci lagi dalam melakukan pendekatan diagnosis Cirrhosis hepatis melalui pemeriksaan-pemeriksaan penunjang.

Setelah mengklasifikasikan ke 100 responden ke dalam kategori Cirrhosis hepatis dan non Cirrbosis hepatis, selanjutnya diklasifikasikan menjadi yang mengalami komplikasi Spontaneous Bacterial Peritonitis. Spontaneous Bacterial Peritonitis dalam penelitian ini ditentukan dari gejala klinis : distensi abdomen, peningkatan leukosit diatas $10.000 \mathrm{sel} / \mathrm{mm}^{3}$, penurunan kadar albumin dibawah 3,5\%, dan peningkatan suhu tubuh (demam) diatas $37^{\circ} \mathrm{C}$.

Cairan asites biasanya hanya mengandung sedikit albumin dan protein-protein opsonik lain yang secara normal berperan protektif terhadap bakteri. (Podolsky, 2005). Oleh karena itu, disebutkan oleh Lingappa (2000), bahwa Cairan asites merupakan medium kultur yang baik untuk beberapa patogen, termasuk Enteobacteriaceae (khususnya E. coli), group D streptokokus (enterokokus), Streptococcus pneumoniae, dan Streptococcus viridan. Menurut Bandy (2006), diagnosa pasti Spontaneous Bacterial Peritonitis selain ditegakkan melalui temuan-temuan klinis seperti demam dan menggigil, nyeri abdomen atau ketidaknyamanan, kadang didapatkan ensefalopati. Juga ditegakkan dengan pemeriksaan laboratorium, seperti leukositosis, dan kultur bakteri (+), serta melalui radiografi abdomen dan foto thorax untuk melihat adanya perforasi atau tidak. Pada penelitian ini tidak dilakukan pengambilan data laboratorium yang spesifik, karena peneliti tidak melihat data kultur cairan asites.

Hasil penelitian menunjukkan, dari 100 orang responden, 51\% mengalami komplikasi Spontaneous Bacterial Peritonitis, sedangkan 49\% lainnya tidak mengalami komplikasi Spontaneous Bacterial Peritonitis. Lalu dengan analisa Uji Chi-Square dan Uji Korelasi, dari keempat gejala klinis yang menjadi patokan tersebut, menunjukkan hubungan yang signifikan terhadap pendekatan diagnosa Spontaneous Bacterial Peritonitis. Hal ini berarti hipotesa yang menyatakan adanya keeratan hubungan antara Cirrhosis hepatis dengan Spontaneous Bacterial Peritonitis, dapat diterima. Dengan kata lain antara Cirrbosis hepatis dengan Spontaneous Bacterial Peritonitis mempunyai keeratan hubungan yang signifikan, dengan arah korelasi yang positif. Hal ini serupa dengan yang dikemukakan oleh Gomersall (2007) bahwa Spontaneous Bacterial Peritonitis merupakan komplikasi yang tersering pada pasien Cirrbosis Hepatis dengan asites, maupun dengan penyakit lain yang disertai asites.

\section{Kesimpulan}

Berdasarkan hasil penelitian yang telah dilakukan untuk mencari hubungan asites pada penderita Cirrhosis Hepatis dengan komplikasi Spontaneous Bacterial Peritonitis, maka dapat ditarik kesimpulan sebagai berikut:

1. Ada hubungan yang signifikan dan keeratan yang positif antara kejadian asites pada penderita Cirrhosis hepatis dengan komplikasi Spontaneous bacterial Peritonitis yang diuji dengan uji Chi-Square dan Koefisien Korelasi.

2. Pendekatan diagnosa Spontaneous bacterial Peritonitis dapat ditegakkan dengan melihat gejala klinis yang diteliti: distensi abdomen, peningkatan leukosit, penurunan kadar albumin, dan peningkatan suhu tubuh, keempat aspek tersebut mempunyai hubungan dan tingkat keeratan yang signifikan yang telah di uji dengan Uji Chi-Square dan Uji Koefisien Korelasi dengan nilai signifikansi (p) < á 0,05 .

3. Dari tabulasi silang penderita asites dengan Cirrhosis Hepatis dan komplikasi Spontaneous Bacterial Peritonitis, menunjukkan bahwa Komplikasi Spontaneous Bacterial Peritonitis lebih banyak muncul pada pasien Cirrbosis Hepatis daripada dengan pasien Non-Cirrhosis Hepatis. 


\section{DAFTAR PUSTAKA}

Anurogo, Dito., Tips Praktis Mengenali Asites : Februari 2009, Availale from URL : www.kabarindonesia.com/berita

Bandy, S.M., et.al. Spontaneous Bacterial Peritonitis: June 2007, Available from URL: University of New Mexico

$\underline{w} \mathrm{w} \cdot \mathrm{E}-\mathrm{m}$ e $\mathrm{d}$ i c i n e c o m / SpontaneousBacterialPeritonitis.org

Cotran, et al., Robbin's Pathologic Basic of Disease; Peritoneum, $6^{\text {th }}$ edition, United States of America: W.B. Saunders company, 1999.p.841-2.

Cotran, et al., Robbin's Pathologic Basic of Disease; The Liver, $6^{\text {th }}$ edition, United States of America: W.B. Saunders company, 1999.p.846-56.

Davey, Pattrick. At a Glance Medicine; Penyakit Hati Akut dan Kronis, Jakarta: EGC, 2007.hal.112-5.

Fallon, M.B., et.al., Cecil's Essentials of Medicine; Fulminant Hepatic Failure, 5 th edition, United States of America : W.B. Saunders company, 2001.p.385-91.

Gomersall, Charles. Ascitic Fluid Infections: February 2007, Available from URL : www.Dragermedical/AsianIntensiveCare/ ProblemsandSolutions.org

Hasan, Irsan., Medicinus; Peran Albumin dalam Penatalaksanaan Sirosis Hati, Jakarta : Dexa Media, 2008. p.3-6.

Levinson, Warren, Medical Microbiology and Immunology ; Gram-Negative Rods Related to the Enteric Tract, $8^{\text {th }}$ edition, United States of America : McGraw-Hill's company, 2004.p.129-45.

Lingappa, V.R., Current Medical Treatment and Diagnosis; Liver Disease. United States of America : McGraw-Hill's company; 2000.p.327-61.

McHutchison, JG., Runyon, BA. Spontaneous bacterial peritonitis; Gastrointestinal and Hepatic Infections, WB Saunders Company, Philadelphia : 1994. p.455.

Nito, Imran., Asites, Cairan dalam Rongga Peritoneal. Februari 2009, Available from URL :

www.imrannito.blogspot.com/2009/02/ asites-cairan-dalam-rongga-peritoneal

Nurdjanah, Siti., Buku Ajar Ilmu Penyakit Dalam; Sirosis Hati. Jakarta : Pusat Penerbitan Ilmu
Penyakit Dalam Fakultas Kedokteran Universitas Indonesia, 2006. p.443-6

Parsi, A.M., et.al., Cleveland Clinic Journal of Medicine; Spontaneous Bacterial Peritonitis: Recent Data on Incidence and Treatment, United States of America : CME, 2004.p.569-76.

Pearce, C.E., Anatomi dan Fisiologi untuk Paramedis; Hati, Kandung Empedu, dan Pankreas. Jakarta : PT. Gramedia. 1999. hal. 201-11.

Podolsky, D.K., Harrison's Principle of Internal Medicine; Cirrhosis and It's Complications, $16^{\text {th }}$ edition, United States of America : McGraw-Hill's company, 2005.p.1859-67.

Rubin, E., Farber, L.J., Essential Pathology; Cirrhosis, $2^{\text {nd }}$ edition, United States of America : J.B. Lippincot company, 1995.p.416-8.

Runyon, B.A., Pathogenesis and Clinical Manifestations of Spontaneous Bacterial Peritonitis: June 2007, Available from URL medical article search www.UpToDate.com/

Sutadi, Sri Maryani., Bagian Ilmu Penyakit Dalam Universitas Sumatera Utara; Sirosis Hepatis : 2003, Available from URL : www.usudigitallibrary.com/ sirosishepatis

Tarigan P., Buku Ajar Ilmu Penyakit Dalam ; Sirosis Hati. Jilid 1. Edisi Ketiga. Jakarta: PB. PAPDI; 1996. p.271-9

Tierney, M.,Jr., Current Medical Treatment and Diagnosis. Cirrhosis. United States of America : Lange; 2004.p.640-5.

Tim Mikrobiologi Fakultas Kedokteran Universitas Brawijaya, Mikrobiologi Kedokteran. Malang : Bayumedia Publishing , 2003.hal.197-211.

Wibowo, Chandra, Farmakoterapi Terkini Virus Hepatitis Kronik. Manado : Universitas Samratulangi, 2003. Thesis

Wilson, Lorraine M., Patofisiologi. Konsep Klinis Proses Penyakit. Vol.2. Jakarta : EGC; 2006. p.630-41.

Wong, Florence. S., The Management of Cirrhotic. Asites: October 2002, Available from URL : www.medscape.com/ medgenmed 
